УДК 336.226

DOI https://doi.org/10.32849/2663-5313/2020.4.34

Ольга Береженна,

здобувач першого (бакалаврського) рівня вищої освіти

Університету державної фіскальної служби Украйни

Тетяна Кулаківська,

здобувач першого (бакалаврського) рівня вищої освіти

Університету державної фіскальної служби Украйни

\title{
ПОДАТКОВЕ РЕГУЛЮВАННЯ АГРОПРОМИСЛОВОГО КОМПЛЕКСУ В УКРАЇНI
}

у статті досліджується історія оподаткування виробників сільськогосподарської продукиіі та наслідки для економіки Украӥни. Встановлено, що, незважаючи на прогресивний розвиток суб'єктів господарювання, які займаються аграрною діяльністю, важливим питанням залишається податковий вплив на розвиток даного сектору. Для того, щоб покращити ефективність функиіонування сільських господарств і забезпечити вихід агропромислового комплексу нашої країни з тривалої кризи, необхідно більш детально дослідити дану проблему.

Сільське господарство є однією з головних галузей в економічі Украйни, при ивому для начіонального господарства ия галузь є однією з основоположних для розвитку національної економіки. Саме тому сучасна система державного регулювання економіки повинна бути спрямована на забезпечення ефективного функиіонуванню даної галузі.

У більшості країн світу основою економіки є саме аграрне виробниитво, в Україні ж даний вид господарської діяльності також займає одне з провідних місиь. Та, незважаючи на важливу роль та користь для держави, розвитку аграрного господарства досить часто перешкоджають різні негативні чинники, одним з яких є саме податкове навантаження. Хоча, для прикладу, в багатьох розвинутих державах дана діяльність або взагалі звільняється від сплати податків, або звільняється на певний проміжок часу, для того щоб особа сформувала свій капітал і вже потім могла сплачувати податки без надмірно20 податкового тягаря. Загалом можна стверджувати, що податкова система України характеризується певною специфікою порівняно з практикою європейських країн. Особливо яскраво така специфіка проявляється у формуванні механізму оподаткування у сільському господарстві.

У статті встановлено, що натепер аграрний сектор виробництва оподатковується або за загальною системою, або за спрощеною системою оподаткування. Та, незважаючи на че, здійснюються й подальші реформи податкового законодавства, які впливають і безпосередньо на сільськогосподарських виробників. Визначені основні недоліки в системі оподаткування агропромислового комплексу та запропоновані можливі шляхи його вдосконалення.

Ключові слова: аграрна діяльність, сектор економіки, сільськогосподарське виробництво, спеціальний режим оподаткування, податки.

Постановка проблеми. Фіскальна політика України щодо аграрного сектору економіки не відзначається комплексністю та системністю, адже вона має низку недоліків, що не забезпечують формування сприятливого інституційного середовища та вирівнювання умов господарювання в галузі. Впроваджуючи податкову політику, держава має обов'язково враховувати інтереси бюджету, господарюючих суб'єктів та споживачів. Поліпшення фінансового стану аграрних підприємств усіх форм власності повинно становити одну з головних цілей податкового регулювання.
Основна проблема української податкової системи полягає в надмірному навантаженні як на бізнес, так і на громадян.

Аналіз останніх досліджень. Даному питанню присвячували свої наукові праці такі вчені, як П. І. Гайдуцький, Д. І. Дема, М. Я. Дем'яненко, С. М. Кваша, П. А. Лайко, П. Т. Саблук, В. П. Синчак, Л. Д. Тулуш, Є. А. Опря та інші.

Мета статті - дослідити історію оподаткування агропромислового сектору економіки України, визначити сучасні тенденції в даній сфері, ознайомитися з нормативноправовою базою. 
Виклад основного матеріалу. Одним iз головних завдань аграрної політики держави є забезпечення високого продовольчого рівня держави, наповнення внутрішнього ринку доступними за ціною та якісними продуктами харчування, створення конкуренції у виробництві та збуті продукції і сільськогосподарської сировини як на внутрішньому, так і на зовнішньому ринку. На сучасному етапі розвитку України важливим є законодавче регулювання діяльності аграрного господарства, оскільки воно становить важливу ланку економіки нашої держави, яка дає прибуток.

Ключовим стимулюючим механізмом системи оподаткування в сільському господарстві раніше було використання спеціального режиму оподаткування податку на додану вартість (ПДВ). Зокрема, діючий механізм оподаткування сільськогосподарських підприємств сприяв збільшенню їх обігових коштів на близько 42 млрд. грн, що насамперед пов'язане зі збільшенням обсягу податкових преференцій підприємствам аграрного сектору економіки України. 31 січня 2017 року спеціальний режим оподаткування ПДВ сільськогосподарських підприємств скасовано, оскільки відповідно до підпункту 4 пункту 2 розділу ХІХ Податкового кодексу України (далі - ПК України) з 01 січня 2017 року стаття 209 ПК України визнається такою, що втратила чинність [1].

Тобто з урахуванням вищевказаних змін в Україні була скасована реєстрація суб'єктів спеціального режиму та переведення їх на загальну систему оподаткування; закриття рахунків у системі електронного адміністрування ПДВ; перенесення від’ємного значення різниці між податковими зобов'язаннями та податковим кредитом, що сформувалася в результаті здійснення сільськогосподарської діяльності до податкової декларації з податку на додану вартість, за якою здійснюються розрахунки з бюджетом [2, с. 34-35].

Варто зазначити, що питання скасування спеціального режиму ПДВ було вимогою Міжнародного валютного фону для надання чергового траншу. В Україні цю ініціативу висловлювало Міністерство фінансів, оперуючи тим, що аграрний сектор дає надто мало податкових надходжень. Натомість витрати на різні види допомоги аграрному сектору сягають мільярди гривень, левову частку 3 яких становить відшкодування ПДВ. Найбільше 3 цих коштів отримують великі сільськогосподарські товаровиробники, які здатні повністю сплачувати ПДВ. Тобто саме це і стало причино скасування сплати ПДВ суб'єктами аграрного сектору в Україні.
Після скасування ПДВ постало питання: яким чином потрібно оподатковувати сільськогосподарських виробників. Для цього в Україні було вирішено оподатковувати таких суб'єктів за загальною системою або ж надати їм право вибирати спрощену систему оподаткування у вигляді єдиного податку IV групи.

Щодо платників податків, які вибирають загальну систему оподаткування, то вони зобов'язані сплачувати такі податки: податок на прибуток, податок на додану вартість, податок на майно (земельний податок), рентну плату за спеціальне використання води.

Оподаткування сільськогосподарських товаровиробників податком на прибуток здійснюється на загальних умовах за ставкою 18\%. 3 липня 2017 року ці товаровиробники мають звітувати щодо названого податку на загальних умовах, адже 01 січня 2017 року ДФС своїм листом від 01 січня 2018 року № 6191/7/99-99-15-02-01-17 «Про особливості декларування податку на прибуток підприємств за 2017 рік» роз'яснила, що у 2017 році припинилося застосування «особливого» звітного періоду для виробників сільськогосподарської продукції. Остання декларація, подана виробниками сільськогосподарської продукції за 2017 рік, складалася за звітний (податковий) період з 01 липня 2016 року до 30 червня 2017 року. Виробники сільськогосподарської продукції з 01 липня 2017 року звітують 3 податку на прибуток підприємств у загальному порядку [3].

Також з 01 січня 2017 року сільськогосподарські товаровиробники сплачують ПДВ на загальних засадах. Особливості переходу на загальну систему оподаткування за цим податком ДФС пояснила у листі від 03 січня 2017 року за № 8/7/99-99-15-03-02. Зокрема, роз'яснення стосувалися «автоматичного» переходу без необхідності подання заяви, закриття додаткових електронних рахунків, подання податкової звітності з ПДВ, реєстрації податкових накладних/розрахунків коригування [4].

Спеціальний режим оподаткування ПДВ розглядався як засіб державної підтримки розвитку аграрної сфери. Тому з метою певної компенсації можливих втрат від скасування спеціального режиму ПДВ Закон України «Про державну підтримку сільського господарства» було доповнено ст. 16-1, що має назву «Бюджетна дотація для розвитку сільськогосподарських товаровиробників та стимулювання виробництва сільськогосподарської продукції» [5].

Новелою оподаткування сільськогосподарських товаровиробників ПДВ є те, що 
тимчасово звільняються від оподаткування ПДВ операції з вивезення за межі митної території України в митному режимі експорту: $з 01$ вересня 2018 року до 31 грудня 2021 року - соєвих бобів; 301 січня 2020 року до 31 грудня 2021 року - насіння свиріпи або ріпаку. Наведені положення не поширюються на сільськогосподарські підприємства - виробників соєвих бобів та насіння свиріпи чи ріпаку, вирощених ними на землях сільськогосподарського призначення, які перебувають у власності таких товаровиробників чи в їхньому постійному користуванні або використовуються ними на правах оренди (суборенди) чи емфітевзису [1] .

Щодо земельного податку, то основні новели були запроваджені у 2015 році. Нині земельний податок є складником плати за землю і входить до податку на майно. Цей податок є ключовим для агробізнесу, оскільки розвиток жодної галузі сільського господарства неможливий без використання землі сільськогосподарського призначення (сільськогосподарські або несільськогосподарські угіддя).

Основою для визначення розміру земельного податку є нормативна грошова оцінка землі, яка підлягає щорічній індексації. Ставки земельного податку встановлюються органами місцевого самоврядування, які до 25 грудня року, що передує звітному, подають відповідному контролюючому органу за місцезнаходженням земельної ділянки рішення щодо ставок земельного податку та наданих пільг зі сплати земельного податку юридичним та/або фізичним особам за встановленою формою.

Конкретні ставки земельного податку можуть встановлюватися в межах ставок податку для сільськогосподарських угідь, нормативну грошову оцінку яких проведено. Ставки встановлюються у розмірі не менше ніж 0,3\% та не більше ніж 1\% від їх нормативної грошової оцінки. Для сільськогосподарських угідь, розташованих за межами населених пунктів, нормативну грошову оцінку яких не проведено, - не менше ніж 0,3\% та не більше ніж 5\% від нормативної грошової оцінки одиниці площі ріллі в області [1].

Стосовно спрощеної системи оподаткування, то вона представлена єдиним податком IV групи. 32018 року коло платників єдиного податку IV групи розширилося через включення до нього фізичних осіб-підприємців, які провадять діяльність виключно у межах фермерського господарства, зареєстрованого відповідно до Закону України «Про фермерське господарство» [6].

Слід звернути увагу також на нововведення, згідно з яким повторне включення до IV групи платників єдиного податку може відбутися не раніше ніж через 2 календарні роки після його переходу на застосування ставки єдиного податку, визначеної для платників іншої групи, або анулювання його попередньої реєстрації платником єдиного податку IV групи.

Базою оподаткування єдиним податком IV групи визначено нормативну грошову оцінку 1 га сільськогосподарських угідь (ріллі, сіножатей, пасовищ і багаторічних насаджень), а для земель водного фонду (внутрішніх водойм, озер, ставків, водосховищ) - нормативну грошову оцінку ріллі в області, враховуючи коефіцієнт індексації, визначений станом на 1 січня базового податкового (звітного) року відповідно до порядку, встановленого ПКУ. Розмір ставок податку з 1 га сільськогосподарських угідь та/або земель водного фонду залежить від типу земель та їх розташування [1].

Також варто звернути увагу, що в Україні нині Законом 1210 вносять зміни до Податкового кодексу і певні положення стосуються безпосередньо осіб, які працюють в аграрному секторі. Даний проект Закону перебуває на стадії підписання Президентом України, та, проаналізувавши його положення, можна звернути увагу на такі нововведення:

- для виробників сільськогосподарської продукції передбачений або звичайний звітний період (квартал або календарний рік), або особливий річний звітний період. Такий особливий період починається 1 липня минулого року і закінчується 30 червня поточного звітного року. Найімовірніше, таким правом вони зможуть скористатися з 1 липня 2020 року;

- фізичним особам у разі отримання винагород та інших виплат за цивільно-правовими договорами від фізичних осіб - платників єдиного податку четвертої групи - не треба подавати декларацію про доходи за звітний рік і самостійно сплачувати ПДФО;

- платник єдиного податку виконує передбачені обов'язки податкового агента у разі нарахування (виплати, надання) оподатковуваних податком на доходи фізичних осіб доходів на користь фізичної особи, яка перебуває з ним у трудових або цивільно-правових відносинах;

- за бажанням зареєстрований платник єдиного податку може безоплатно та безумовно у контролюючому органі за місцем податкової адреси отримати (у тому числі в електронному вигляді) витяг з реєстру платників єдиного податку. Строк надання витягу не повинен перевищувати одного робочого дня 3 дня надходження запиту. Витяг діє до внесення змін до реєстру [7].

Варто зазначити, що нинішня ситуація в сільському господарстві свідчить про недостатню ефективність податкової системи як методу непрямої державної підтримки, в якій є безліч недоліків. 
По-перше, нині в Україні відсутня довгострокова стратегія щодо розвитку аграрного бізнесу, і значним стримувальним чинником у його розвитку є саме недосконалість нормативної бази, і не можна стверджувати, що вона $є$ відпрацьована достатньо і діє безвідмовно. По-друге, одним з основних недоліків і прорахунків є ігнорування специфіки продовольчого виробництва, тому варто було би побудувати їі таким чином, щоб через неї передбачалося створення умов для товаровиробника, за яких він був би зацікавлений у збільшенні доходів, а натепер у нашій країні вона спрямована в протилежному напрямі. По-третє, розвиток аграрного бізнесу не можна забезпечити за рахунок лише закликів, гасел чи навіть досконалої законодавчої бази. Фундаментальна ідея ринкової економіки - це ідея вільної конкуренції [9, с. 52].

Таким чином, належне виконання наведених завдань організаційно-економічного механізму розвитку агробізнесу в Україні необхідно насамперед пов'язувати з розробкою державної стратегії податкової політики, чітким розмежуванням функцій держави і ринкового саморегулювання, переходом до ринкових методів аграрної та продовольчої політики [10, с. 159].

Багато науковців стверджують, що внесення подальших змін до ПКУ в частині оподаткування аграрних товаровиробників повинно здійснюватись із дотриманням таких вимог: врахування особливостей сільськогосподарського товаровиробництва; однакове відношення до всіх сільськогосподарських товаровиробників; необхідно враховувати взаємозалежність сільськогосподарських підприємств та інших господарюючих суб'єктів; побудувати систему оподаткування на базі плати за землю та рівномірного податкового навантаження з урахуванням дохідності виробництва; забезпечити малим сільськогосподарським підприємствам об'єктивні пільги та преференції в оподаткуванні [8, с. 426].

\section{Висновки}

Отже, незважаючи на всі зміни, які здійснюють у сфері оподаткування, завжди залишаються як негативні, так і позитивні сторони. Нинішня ситуація в сільському господарстві свідчить про недостатню ефективність податкової системи як методу непрямої державної підтримки. Саме тому необхідно і надалі вдосконалювати податкове законодавство. Насамперед необхідно забезпечити його стабільність, що дасть можливість сільськогосподарським товаровиробникам адаптуватись до нього та чітко вибирати для себе оптимальний варіант оподаткування (загальну чи спрощену систему), здійснювати аналіз і розробку пропозицій щодо оптимізації оподаткування агробізнесу. Адже в Україні досить часто відбуваються зміни податкового законодавства, і це є дуже вагомою перепоною стабільного розвитку агропромислового сектору.

\section{Список використаних джерел:}

1. Податковий Кодекс України: кодекс України від 02 грудня 2010 р. № 2755-VI. Вiдомості Верховної Ради Україн. URL: http:// zakon2.rada.gov.ua/laws/show/2755-17 (дата звернення: 10.03.2020)

2. Лагодієнко Н. В. Сучасні тенденції податкового регулювання аграрного сектору економіки в Україні. II Міжнародної науково-практичної конференції «Обліково-аналітичне і фінансове забезпечення діяльності суб'єктів господарювання: освітньо-наукові та виробничі засади» 22-24 листопада 2017 р. Миколаїв : МНАУ, 2017. С. 33-36.

3. Проособливостідекларуванняподаткунаприбуток підприємств за 2017 рік: Лист ДФС України від 01.03.2018p.№6191/7/99-99-15-02-01-17URL:http:// sfs.gov.ua/zakonodavstvo/podatkove-zakonodavstvo/ listi-dps/72853.html (дата звернення: 10.03.2020)

4. Про скасування спеціального режиму оподаткування діяльності у сфері сільського та лісового господарства, а також рибальства: Лист ДФС України від 03.01.2017 р. за №8/7/99-99-15-03-02 URL: http://sfs.gov.ua/ zakonodavstvo/podatkove-zakonodavstvo/listi-dps/70807. html (дата звернення: 11.03.2020)

5. Про державну підтримку сільського господарства: Закон України від 24.06.2004 № 1877-IV Відомості Верховної Ради України. URL: https:// zakon.rada.gov.ua/laws/show/1877-15 (дата звернення: 12.03.2020)

6. Про фермерські господарства: Закон України від 19.06.2003 № 973-IV Відомості Верховної Ради України. URL: https://zakon.rada.gov.ua/ laws/show/973-15 (дата звернення: 12.03.2020)

7. Про внесення змін до Податкового кодексу України щодо вдосконалення адміністрування податків, усунення технічних та логічних неузгодженостей у податковому законодавстві: Проект Закону України від 30.08.2019 р. № 1210 . URL: http://search.ligazakon.ua/1_doc2.nsf/link1/ JI00230A.html (дата звернення: 13.03.2020).

8. Заболотний В.С. Оподаткування сільськогосподарських підприємств в Україні: проблеми та перспективи. Perspectives of world science and education. Abstracts of the 3rd International scientific and practical conference. CPN Publishing Group. Osaka, Japan. 2019. C. $422-427$ URL: http:// sciconf.com.ua (дата звернення: 13.03.2020).

9. Босенко А. В. Організаційно-економічний механізм управління оподаткуванням сільськогосподарських товаровиробників в умовах поглиблення інтеграційних процесів: дис. канд. екон. наук: 08.00.03. Кіровоград, 2016. 271 с.

10. Ковальчук I. В. Гармонізація податкового законодавства України та ЄС у сфері оподаткування агробізнесу. Polish science journal (issue 2(23), 2020). Warsaw: Sp. z 0. o. «iScience». C. 157-161. 
The article examines the history of taxation of agricultural producers and the consequences for the economy of Ukraine. It is established that, despite the progressive development of agricultural entities, tax impact on the development of the sector remains an important issue. In order to improve the efficiency of functioning of agriculture and ensure the exit of the agro-industrial complex of our country from the prolonged crisis, it is necessary to investigate this problem in more detail.

Agriculture is one of the major industries in the economy Ukraine, while for the national economy, this industry is one of the fundamental for the development of the national economy. That is why, acting the system of state regulation of the economy should be aimed at ensuring the effective functioning of the industry.

In most countries of the world, the basis of the economy is agricultural production, in Ukraine, this type of economic activity also occupies one of the leading places. However, despite the important role and benefits for the state, the development of agrarian economy is often hampered by various negative factors, one of which is the tax burden itself. Although, for example, in many developed countries, this activity is either tax exempt at all or exempt for a certain period of time, so that a person can form his capital and then be able to pay taxes without undue tax burden. In general, it can be argued that the tax system of Ukraine is characterized by a certain specificity in comparison with the practice of European countries. Particularly striking is this specificity when forming the mechanism of taxation in agriculture.

The article found that today the agricultural sector of production is taxed either under the general system or the simplified system of taxation. However, further reforms are being made to tax legislation that affect farmers directly. The main shortcomings in the taxation system of the agroindustrial complex were identified and possible ways of improvement were suggested.

Key words: agrarian activity, economy sector, agricultural production, special taxation regime, taxes. 